\title{
Influence of Desert Saltbush Saponin on Germination ${ }^{1}$
}

\section{LEONARD R. ASKHAM AND DONALD R CORNELIUS}

Research Assistant, California Agricultural Experiment Station, Berheley, California; and Range Scientist, Crops Research Division, Agricultural Research Service, U. S. Department of Agriculture, Berkeley, California.

\section{Highlight}

A plant-produced chemical, saponin, was identified, extracted from desert saltbush, tested and quantitatively analyzed. Desert saltbush, Trigo pubescent wheatgrass, Harbinger medic, and California ephedra seeds were subjected to different concentration levels of leachates extracted from desert saltbush vegetation. These leachate solutions reduced the germination of desert saltbush, Harbinger medic, and Trigo pubescent wheatgrass. California ephedra germination was stimulated at low leachate concentration but was retarded at higher leachate concentrations.

The purpose of this study was to determine the presence of saponin in various parts of desert saltbush (Atriplex polycarpa (Torr.) S. Wats.) to analyze it quantitatively and to determine the effects of different levels of saponin on seed germination. We tested leachate from the desert saltbush vegetation on germinating seed of four different plant species, as follows: desert saltbush; Trigo pubescent wheatgrass (Agropyron trichophorum (Link) Richt.), Harbinger medic (Medicago littoralis Rohde), and California ephedra (Ephedra californica $\mathrm{S}$. Wats.).

${ }^{1}$ Cooperative investigations of the Crops Research Division, Agricultural Research Service, U. S. Department of Agriculture and the California Agricultural Experiment Station, Berkeley, California. Received October 24, 1970.
Desert saltbush has been rated as a highly palatable browse plant for domestic livestock and big game animals (Sampson and Jespersen, 1963). Also, desert saltbush provides excellent cover for quail and chukar on dry rangeland in central and southern California. Efforts to increase the stands of this species and other saltbush species have met with some difficulty due to poor seed germination. The presence of saponin in seed of fourwing saltbush (Atriplex canescens (Pursh) Nutt.) was reported by Nord and Van Atta (1960) and was believed to inhibit germination of the seed. A growth inhibitor was likewise found by Cornelius and Hylton (1969) in seed of Atriplex polycarpa; it reduced germination but could be removed as a water soluble leachate and increase germination.
Considerable work has been accomplished in determination of alfalfa and clover saponins because they are considered a factor in the bloat of ruminants. Thompson et al. (1957) reported that the saponin content in alfalfa meal was $0.12 \%$ and in Ladino clover $0.23 \%$ of the dry weight.

\section{Methods}

Desert saltbush plants were collected for this study in the Panoche Hills near Mercy Hot Springs, California. The collection area is in the foothills of the eastern slope of the coast range mountains approximately 55 miles west of Fresno, California. The climate is Mediterranean and the vegetation is an annual grassland community with some sparse shrubs as low overstory.

Five desert saltbush plants were selected as representative of the general population in age, vigor and relative amount of green material present. Length, width, height and area of each plant were measured. Eight inches of succulent new growth was clipped from the outer portions of each plant to simulate browsing by livestock. The remainder of the plant was cut to ground level and kept as a separate sample. The sample parts of each plant were dried at $72 \mathrm{C}$ for two days, ground, weighed and stored in plastic lined paper bags.

Each plant produced an average of $64 \mathrm{~g}$ of stems, twigs, and leaves per 268.80 square $\mathrm{cm}$ of soil surface area. This amount was used as 
a standard. The material was ground, boiled in $250 \mathrm{ml}$ of distilled water for 20 minutes, cooled and filtered through cheesecloth to remove the coarser material. Three levels of leachate below the standard were prepared, each in $250 \mathrm{ml}$ of water, by taking 32,16 and $8 \mathrm{~g}$ of ground material. In addition two solutions were prepared by using 128 and $192 \mathrm{~g}$ of ground material in $250 \mathrm{ml}$ of water. The solutions were stored in Erlenmeyer flasks under refrigeration to prevent decompositon by bacteria.

Since the original objective was to determine if the plant material itself held any saponin, a staining reagent was prepared, after the method of Van Atta and Guggolz (1958). This method resulted in the positive identification of saponin in the leafy material of saltbush, and further indicated that the tender twigs have a more positive reaction than did the central material. These observations were closely related to those of Pedersen et al. (1967) who found that saponin was mainly concentrated in the leaves of the alfalfa plant.

A saponin extraction method, closely following the work of Nord and Van Atta (1960) and, with the personal assistance of Mr. Jack Guggolz, was developed. This extraction yielded $2.493 \mathrm{~g}$ of saponin from $215.49 \mathrm{~g}$ of leafy material which was $1.15 \%$ saponin in the leafy material from desert saltbush on dry weight basis. To insure that the material was saponin, the staining reagent test, as described under "Saponin Identification," was made. The results were positive.

Square plastic petri dishes, $9 \mathrm{~mm}$ $\times 9 \mathrm{~mm} \times 3 \mathrm{~mm}$ were used in making germination tests. A square blue blotter with 100 indentations fit in the bottom of each dish. Each level of the leachate and a control with distilled water were testcd on four species of range plants; Harbinger medic, desert saltbush, Trigo pubescent wheatgrass and California ephedra. Each test included four replications with 25 seeds per petri dish per replication.

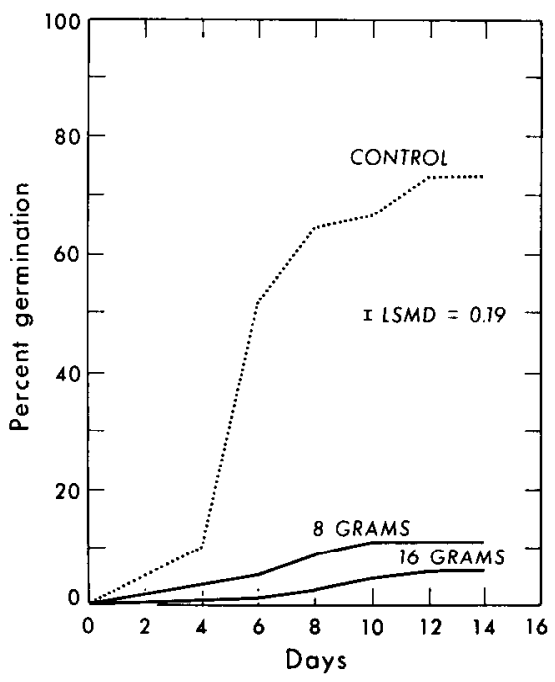

FIc. 1. Germination rates of Medicago littoralis in Petri dishes as affected by concentrations of Atriplex polycarpa leachates.

\section{Results}

Saponin inhibited or reduced germination. The effect of saponin increased as the concentration of the saponin became greater. Each species of plant included in the test responded in a different manner; some were affected more than others by the occurrence of saponin.

\section{Harbinger Medic}

The germination of treated Harbinger medic was low in this experiment (Fig. 1). Over $70 \%$ of the seeds in the control solution (water only) germinated by the 14th day;
$10 \%$ germinated in the $8 \mathrm{~g}$ solution, and $5 \%$ in the $16 \mathrm{~g}$ solution. Stronger solutions of $32 \mathrm{~g}$ and over completely retarded germination. Almost all seeds turned black and were covered by a white feathery fungus. The results of this test showed significant mean difference of 0.19 and a variance of $\mathbf{0 . 0 9}$.

\section{Desert Saltbush}

Saltbush germination was lower than the Harbinger medic. Germination of the control did not exceed $10 \%$; the $16 \mathrm{~g}$ solution achieved only $3 \%$, and the $8 \mathrm{~g}$ solution only $1 \%$ (Fig. 2). The other solutions of higher rates completely inhibited germination. Sixty percent of the utricles had been damaged by insects, leaving only $40 \%$ capable of germination. Readjusting the germination rate, according to the percent of seed not damaged by insects, does not alter the fact that germination of desert saltbush is generally low. This phenomenon may be accounted for, in large part, by the presence of saponin in the seed coats, i.e., saponin appears to retard germination of the seed. The results (Fig. 2) were significant at the $1 \%$ level, with a variance of 0.10 . The least significant difference at the $1 \%$ level was 1.16 .

\section{California Ephedra}

This shrub has some grazing value and great drought resistance. It provides watershed cover and

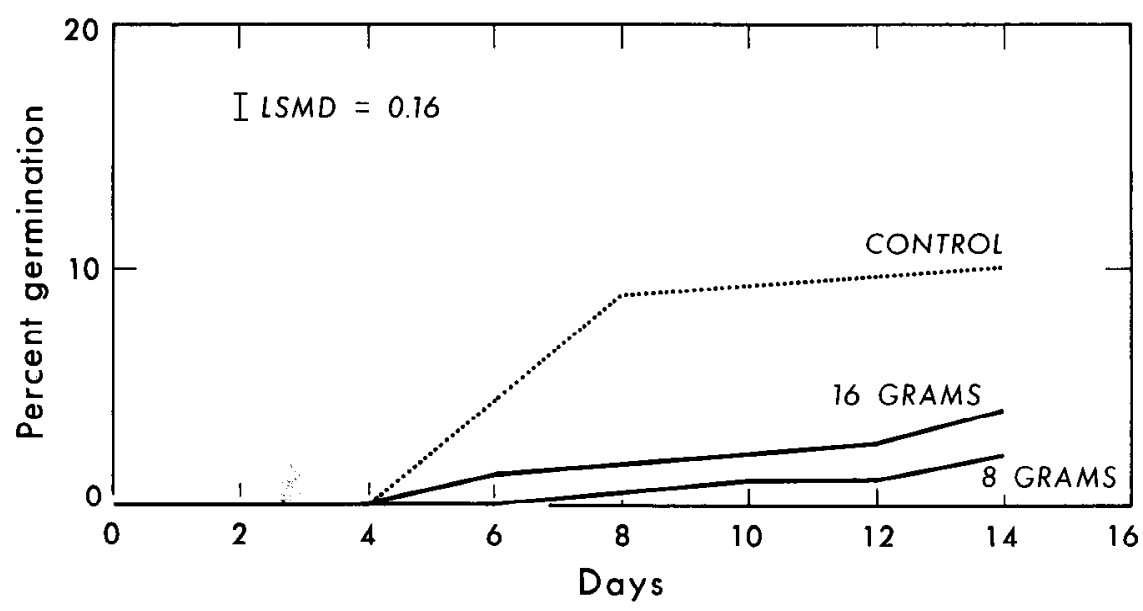

FIG. 2. Germination rates of Atriplex polycarpa in Petri dishes as affected by concentrations of Atriplex polycarpa leachates. 


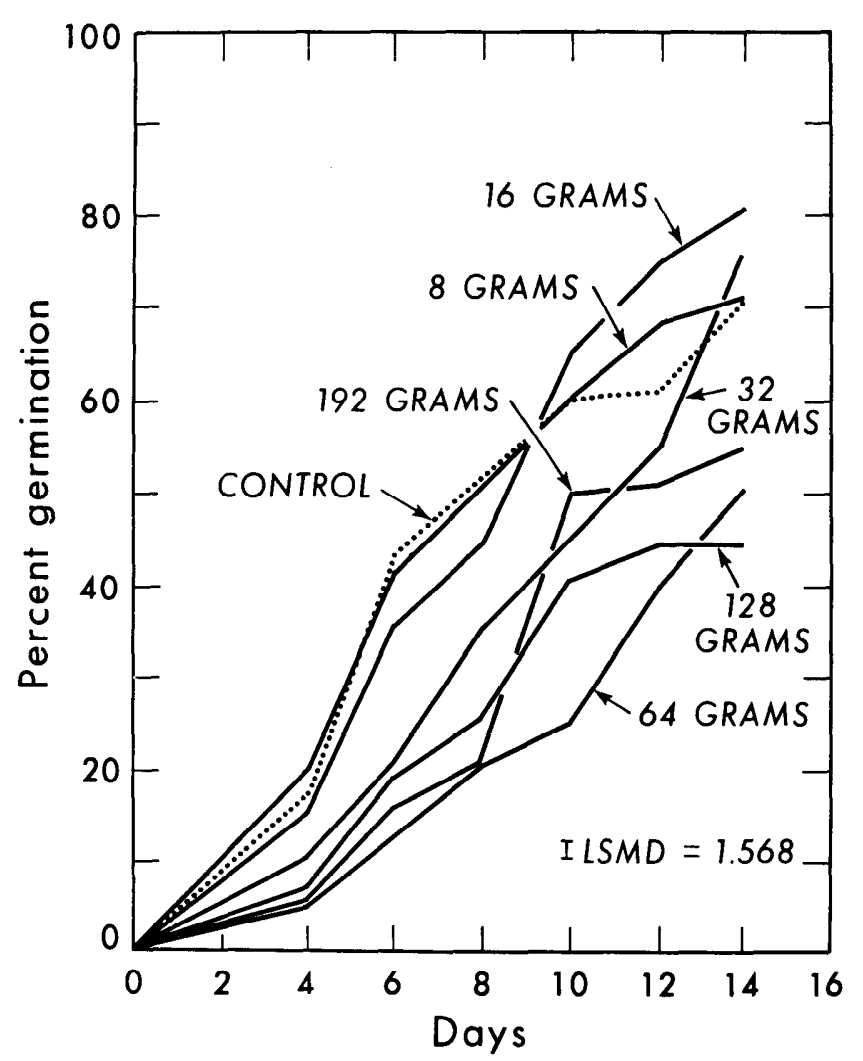

Fig. 3. Germination rates of Ephedra californica in Petri dishes as affected by concentrations of Atriplex polycarpa leachates.

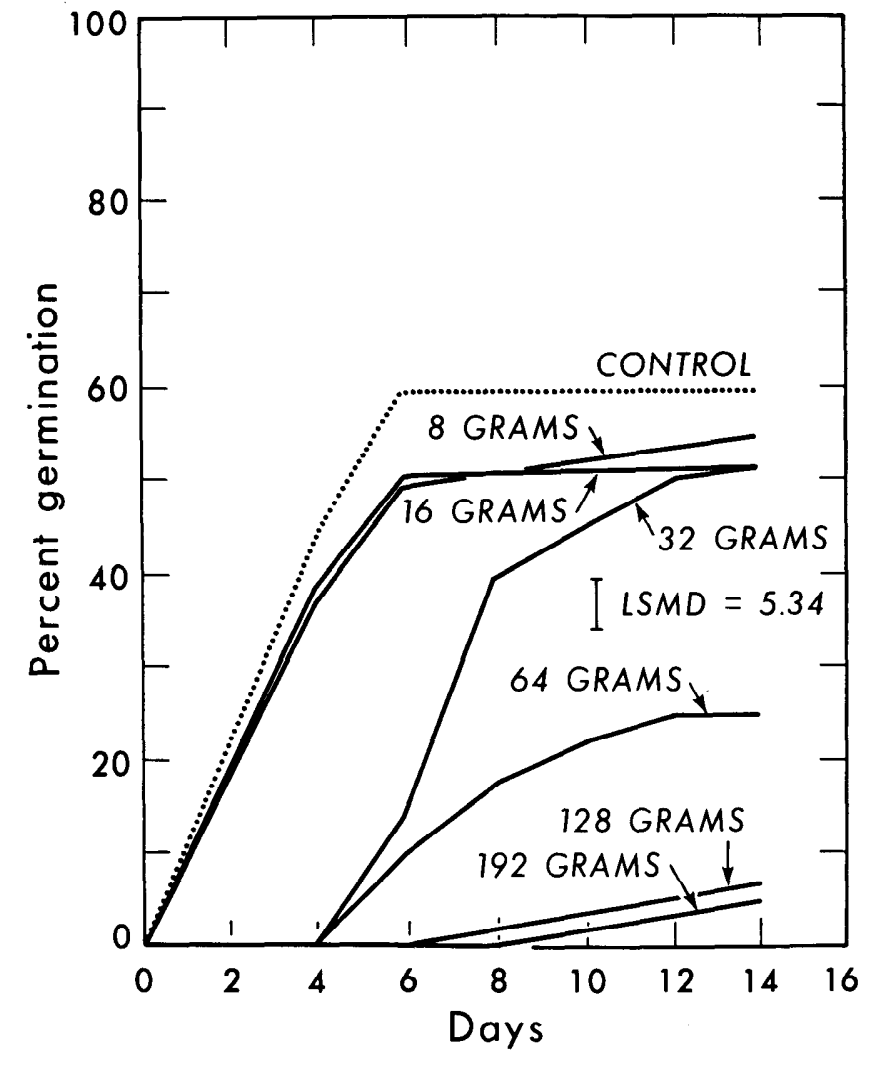

Fig. 4. Germination of Agropyron trichophorum in Petri dishes as affected by concentrations of Atriplex polycarpa leachates. aids in gulley control on steep hillsides and swales. The effects of saponin on the germination of seed of California ephedra were not as great as those found on desert saltbush. The control set that received water only germinated $70 \%$ (Fig. $3)$ and $49 \%$ in the $126 \mathrm{~g}$ solution. Germination in the $192 \mathrm{~g}$ solution deviated from the expected pattern, with germination slightly higher than in the $64 \mathrm{~g}$ solution.

Stimulatory effects occurred with the $8 \mathrm{~g}, 16 \mathrm{~g}$ and $32 \mathrm{~g}$ solutions. The $8 \mathrm{~g}$ solution had a slight increase in germination over the seed germinated with water only. The $16 \mathrm{~g}$ solution increased germination to more than $80 \%$, or $10 \%$ more than the control. The $32 \mathrm{~g}$ solution resulted in $70 \%$ germination and exceeded the control after the 12th day of the test. These results indicate that a large amount of saponin may be detrimental to germination of California ephedra, but that low rates are favorable to germination. The results for different levels of the solution were all significant at the $1 \%$ level with a least significant mean difference of 1.568 and a variance of 0.08 .

The results of this study are in agreement with the work of Varshney and Faroog (1953) and Mishustin and Naumova (1955) who reported that saponin, in small quantities, stimulated germination. Nord and Van Atta (1960), working with fourwing saltbush, found that high concentrations of 1.0 or $5.0 \%$ saponin greatly reduced germination, while a solution of $0.1 \%$ stimulated germination. The saponin content of vegetative material of desert saltbush was $1.15 \%$ on a dry weight basis. The $62 \mathrm{~g}$ solution had $.285 \%$ saponin; $32 \mathrm{~g}$ solution, . $160 \%$ saponin; $16 \mathrm{~g}$ solution, .074\% saponin; and $8 \mathrm{~g}$ solution, $.037 \%$ saponin. Therefore, with California ephedra, the $.074 \%$ solution of saponin appears to be the optimal concentration for stimulating germination.

\section{Trigo Pubescent Wheatgrass}

Trigo pubescent wheatgrass showed a wide range of germination between the control and the $192 \mathrm{~g}$ solutions (Fig. 4). The seeds in the control treatment and in $8 \mathrm{~g}$ and $16 \mathrm{~g}$ solutions germinated rapidly to the 5th day and then leveled off. The control treatment gave the highest germination, $60 \%$, while the $8 \mathrm{~g}, 16 \mathrm{~g}$ and $32 \mathrm{~g}$ solutions reduced germination. The $128 \mathrm{~g}$ and $192 \mathrm{~g}$ solutions showed the greatest reduction in germination. Germination did not begin until the 6th and 8th days, respcctivcly, and did not exceed $5 \%$ at the end of the experiment.

\section{Conclusions}

Saponin was definitely present in the vegetative parts of desert saltbush, as shown by the staining method with acetic anhydride and sulfuric acid mixture. Quantitative extraction by use of the cholesterolfullers earth method indicated a 
percentage content of 1.15 for saponin from the leafy portions of the desert saltbush on a dry weight basis.

The saponin reduced seed germination in the case of desert saltbush and Harbinger medic most markedly. Trigo pubescent wheatgrass and California ephedra had a higher percentage of germination and showed less inhibitory action of the saponin. Lower concentrations were stimulatory for germination of the California ephedra.

\section{Literature Cited}

Cornelius, Donald R., ANd L. O. HylTON. 1969. Influence of temperature and leachate from seed on germination of Atriplex polycarpa. Agron. J. 61:209-211.
Mishustin, B. N., and A. N. Naumova. 1955. Secretion of toxic substances of alfalfa and their influence upon cotton and soil microflora. Akademiia Nauk. U.S.S.R. Izvestia, ser. Biol. pp. 3-9.

Nord, Eamor C., and George Van Atra. 1960. Saponin-a seed germination inhibitor. Forest Sci. 6: 350-353.

Pedersen, M. W., D. E. Zimmer, D. R. MĆAllister, J. O. ANDERSON, M. D. Wilding, G. A. Taylor, and C. F. McGuire. 1967. Comparative studies of saponin of several alfalfa varieties using chemical and biochemical assays. Crop Sci. 7:349-353.

Sampson, Arthur W., and Beryl JesPERSEN. 1963. California range brushland and browse plants. Calif. Agr. Exp. Sta. Manual 33. 162 p.

Thompson, G. R., G. R. Van Atta, E. M. Bickoff, E. D. WALTER, A. L.
Livingston, AND JACK GugGolz. 1957. Preparation and chemistry of legume saponins. pp. $63-70$ in 'Alfalfa saponins-studies on their chemical, pharmacological and physiological properties in relation to ruminant bloat' U. S. Dep. Agr. Tech. Bull. 1161. 83 p.

Van Atta, G. R., and Jack Guggolz. 1958. Forage constituents: Detection of saponins and saponins on paper chromatograms by LiebermannBurchard Reagent. J. Agr. and Food Chem. 6(11):849-850.

Varshney, I. P., and Faroog. 1953. Etude l'influence d'une nouvelle saponine d'Albizzia lebbek, Benth, sur la germination et la croissance des graines de pois chiche (Cicer arietinum, Linn.) et d'orge (Hordeum vulgare, Linn.) Bull. Soc. Chem. Biol. 35:827-830. 